\title{
Particular Aspects of Entrepreneurship in Real Estate Market in Latvia
}

\author{
Linda Kauškale ${ }^{1}$, Ineta Geipele ${ }^{2},{ }^{1,2}$ Riga Technical University
}

\begin{abstract}
The purpose of the study is to determine particular aspects of entrepreneurship in the real estate market in order to provide proposals for the companies operating in the real estate market. The comparative method, historical approach method, data analysis and expert assessment method have been used in the study. The results of the study and developed recommendations can be applied to improvement of the operational efficiency and work planning of the companies operating in the industry.
\end{abstract}

Keywords - Company management, construction, entrepreneurship, real estate market, real estate operations.

\section{INTRODUCTION}

Business results are determined by several factors; therefore, the companies need continuously to improve their efficiency, especially in the real estate trading market. The decisions of the market participants, particularly the decisions of the government and business sector have also a large social significance. Several peculiarities of the industry require a more detailed study, which should be taken into account by the entrepreneurs when conducting market analysis and developing business strategy.

Relevance of the study is determined by the fact that the business sector representatives operating in the real estate market and the construction sector should make decisions in accordance with a number of real estate market peculiarities that make it different from other industries. Real estate market development is affected by internal and external factors, including the economic development of the country, as well as international events in the economic and financial markets. It has also been proved that the housing sector is dynamically sensitive to the monetary policy shocks (Liu and London, 2013).

The aim of the study is to determine the particular aspects of entrepreneurship in the real estate market in order to provide scientific business proposals for the companies operating in the real estate trading market.

The following tasks have been set in order to achieve the aim of the study:

- to explore thematic scientific-research literature, as well as related scientific articles;

- to understand the essence of the immovable goods and real estate trading market and to identify the peculiarities;

- to collect and process statistical data on the real estate market and to determine its development impact on the business sector;

- to explore the real estate sector and to find solutions for the competitiveness improvement of the companies operating in the real estate industry;
- to summarize the results of the study and to develop proposals for the companies operating in the real estate market.

The comparative method, historical approach method, data analysis and expert assessment method have been used in the study. Special attention has been paid to comparative method and data analysis methods, as particular aspects of entrepreneurship in real estate market have been defined by comparing it with other industries and defining the changes within the period of research. The results of the study and developed recommendations can be applied to improvement of the operational efficiency and work planning of the companies operating in the industry.

\section{LITERATURE REVIEW}

Competitiveness of enterprises, development of the industry and national economic development are interrelated (see Fig. 1), so the operation efficiency of the real estate market participants has also a significant impact on other processes.

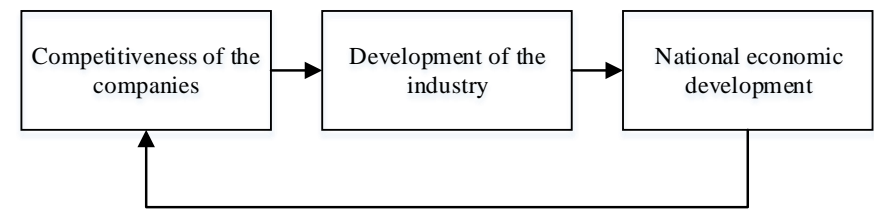

Fig. 1. Interrelation of the economic subjects and processes (Denisovs and Judrupa, 2008).

Real estate market peculiarities in comparison with other financial assets are the following (Asaul, 2004):

1. The need for high "threshold" investment level;

2. The need for control;

3. Heterogeneity of real estate;

4. Protectability of income against inflation;

5. High transaction costs;

6. Peculiarities of pricing;

7. Low correlation of income from real estate with income from financial assets;

8. Preservation of invested funds.

Many of the above-mentioned factors are essential for the operation in the real estate. At the same time, such factors as protectability of income against inflation and the preservation of the invested funds are true only in case of well-considered and estimated decisions about investments. The following activities within the enterprise should be primarily applied to the objects of decision-making (Lapigin, Y. and Lapigin, D., 2009):

- strategic planning;

- development of tactical and operational plans; 
- innovative development;

- organization of production processes;

- marketing activity;

- development of organizational culture;

- economic and financial development;

- accounting and human resource activities.

Companies operating in the real estate industry should take into account a number of peculiarities of immovable goods, the complexity of these goods, as well as the importance of direct sales. The real estate market can be defined as a user market. The differences between the consumer market and user market are presented in Table I.

TABLE I

THE DIFFERENCES BETWEEN THE CONSUMER MARKET AND USER MARKET (GEIPELE, 2007)

\begin{tabular}{|l|l|}
\hline \multicolumn{1}{|c|}{ Consumer market } & \multicolumn{1}{c|}{ User market } \\
\hline - large number of buyers & - relatively small number of \\
- relatively small output value & buyers \\
- buying motive - emotional & - relatively high production \\
- relatively frequent purchases & value \\
- standard goods & - buying motive - rational \\
- short life & - relatively rare purchases \\
- advertising has a large impact & - lomplex products \\
& - the focus is on direct sales \\
\hline
\end{tabular}

The real estate market is also characterized by the special features of its operation.

Functioning of the construction market is determined by the following factors (Construction Economics, 2009):

- Presence of various forms of ownership in the construction industry;

- Free entrepreneurial activities of participants of investment and construction process;

- Free pricing for construction products;

- Contractual relationship between equal participants in the creation of construction products;

- Free competition between the participants in the investment and construction process;

- Presence of anti-monopoly legislation;

- Existence of the financial market;

- Insurance of construction risks and forced control of bankrupt enterprises.

Enterprises operating in the construction industry should take into account a number of risks, which depend both on the size of the project and its implementation period (see Table II).

TABLE II

THE Risks SPECIFIC TO the PROJECT, DEPENDING ON THE PROJECT LIFE (UZULĀNS, 2004)

\begin{tabular}{|l|l|}
\hline Project life & Risks specific to the project \\
\hline $\begin{array}{l}\text { Short-term } \\
\text { project }\end{array}$ & $\begin{array}{l}\text { - insufficient control of the project implementation or } \\
\text { failure to comply with the necessary requirements for } \\
\text { project management }\end{array}$ \\
& - insufficient adequate resources for project management \\
\hline $\begin{array}{l}\text { Average-term } \\
\text { project }\end{array}$ & $\begin{array}{l}\text { - failure to comply with the necessary requirements for } \\
\text { project management }\end{array}$ \\
& $\begin{array}{l}\text { - insufficient resources for organization of the project } \\
\text { team work }\end{array}$ \\
& insufficient cooperation between the project participants \\
\hline
\end{tabular}

\begin{tabular}{|l|l|}
\hline $\begin{array}{l}\text { Long-term } \\
\text { project }\end{array}$ & $\begin{array}{l}\text { - the project does not provide for making changes in } \\
\text { the resources if the economic situation of the } \\
\text { company or the priorities of the company are } \\
\text { changing }\end{array}$ \\
& $\begin{array}{l}\text { - project does not provide for making changes in the } \\
\text { resources in case of changes in the state economic and } \\
\text { political position } \\
\text { - insufficient resources for organization of the project } \\
\text { team work } \\
\text { - insufficient cooperation between the project } \\
\text { participants } \\
\text { insufficient cooperation between the project } \\
\text { originator and the project contractor }\end{array}$ \\
\hline
\end{tabular}

It can be determined by the factors affecting the competitiveness of the company, whether the operation of a particular company is effective (Forands, 2009):

- Increase in the number of consumers;

- Market share stability and expansion in relation to competitors;

- Optimal implementation of the developed strategy;

- Achievement of the objectives within the planned period;

- Timely identification of market demand and market segmentation;

- Acquisition of profit;

- Activation of innovations;

- Creativity of strategies and compliance with the changes of situation;

- Lower product costs in relation to competitors and the product costs itself;

- Efficiency of the scientific research;

- Mastering of new technologies;

- Full use of production capacity;

- Dealer network expansion.

Since the real estate market is characterized by many features, the careful analysis of external and internal factors of influence is required before making decisions. It is necessary to choose the right strategy in order to achieve the set goals. In the service sector, including the real estate trading market, the special attention should be paid to consumer attitude towards the company and/or product research. The criteria could be the following (Forands, 2009):

- Quick response to customer needs;

- Compliance with the deadlines;

- Readiness to advise;

- Technical feasibilities;

- High service culture;

- Solid staff experience;

- Dynamism;

- Amplitude of the range of services;

- Additional services;

- Utilization options.

The aspects defined in ISO 9004 should be taken into account by the senior management of the organization by formulating their quality policy (Leilands, 2009):

- Required future improvements;

- Desired level of customer satisfaction;

- Professional development of the staff;

- Needs of other parties concerned;

- Required resources for achievement of the objectives; 
- Potential contribution of suppliers and partners.

The level of motivation that entrepreneurs are willing to invest may be indicated by entrepreneurial goal intentions (Gielnik et al., 2014). It is important to mention that managers and employees increasingly take part in business activities when behavior is well-designed and widely known (Kuratko et al., 2014). At the same time, real estate market demands form participants' fast reaction to changes. Shane and Delmar (2004) in research results defined that when developing a business plan, first, entrepreneurs can reduce the likelihood of termination of new venture.

Regular market detailed studies, risk analysis and continuous improvement of the companies can help any company operate in the real estate market to achieve high business performance.

\section{PRACTICAL RESEARCH}

By analyzing real estate market, it is important to analyze the developmental trends of individual segments. During the period from 2008 to 2013, the largest amount of funds has been invested in engineering, following by non-residential and residential buildings. The construction of residential and nonresidential buildings, as well as civil engineering has seasonal nature (see Fig. 2).

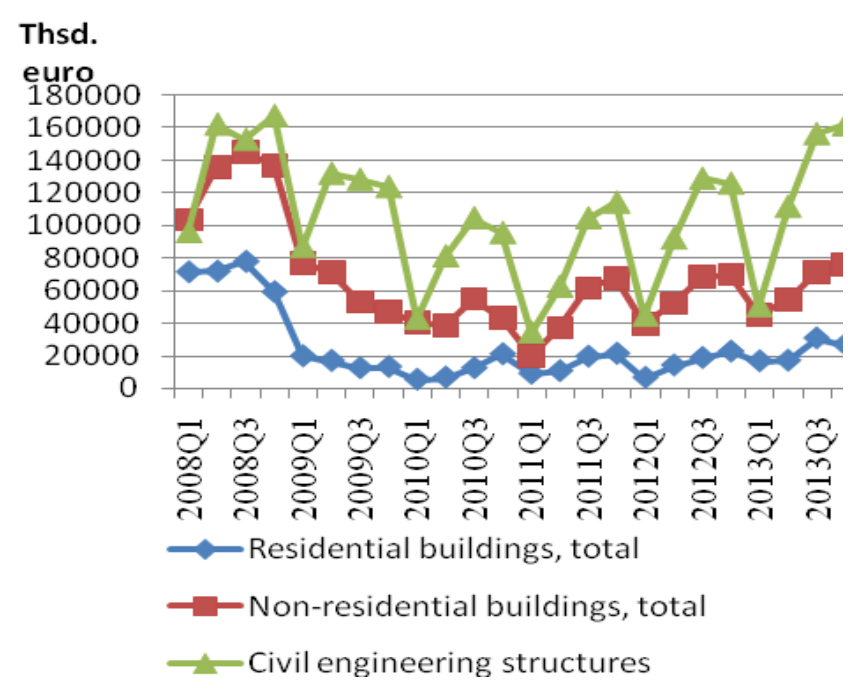

Fig. 2. Construction of residential, non-residential buildings and civil engineering structures by quarters, at current prices, thsd. euro (NACE Rev. 2.) Data source: Central Statistical Bureau of Latvia, the line diagram was made by the authors.

The special attention should be drawn to price changes and their forecasting during operation in the real estate market. Fig. 3 shows that the real estate price fluctuations are much more pronounced than the consumer price fluctuations. Real estate industry differs from other sectors; price fluctuations and pricing peculiarities must be taken into account in strategy planning and development.

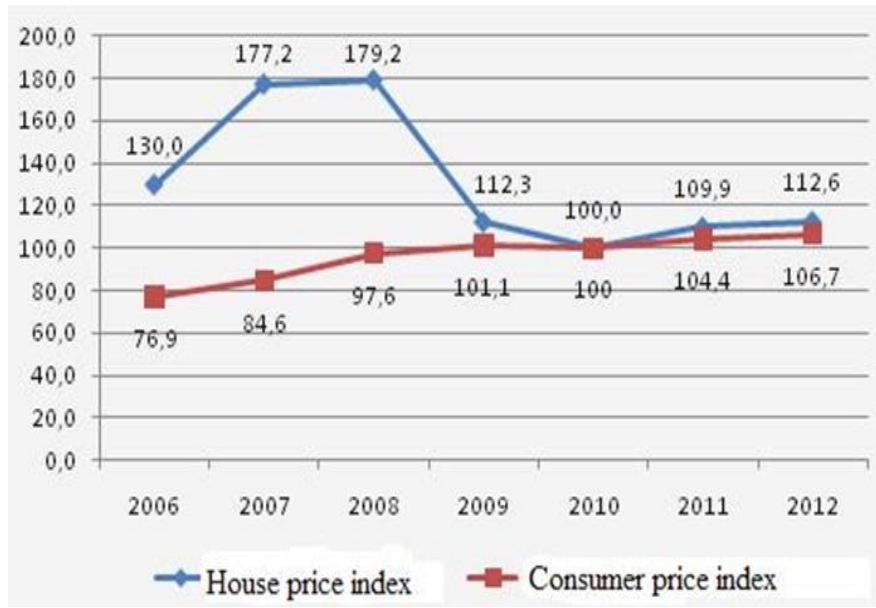

Fig. 3. House price index and consumer price index, $2010=100$, the figure made by the authors. Data source: Eurostat, Central Statistical Bureau of Latvia.

Many construction projects are long-term projects. The long-term project risks do not always bring about changes in the resources, if the economic and political situation as well as insufficient cooperation among the project participants poses one of the possible risks, especially in smaller enterprises. Size of enterprise is one of the important indicators in construction branch, and it is shown in Fig. 4.

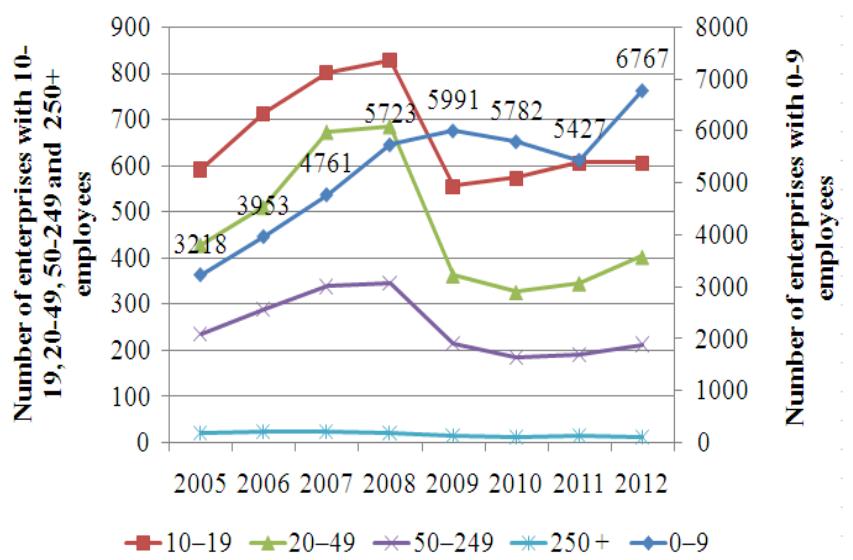

Fig. 4. Construction by employment size class in Latvia. Data source: Central Statistical Bureau of Latvia, the line diagram was made by the authors.

In the time period from 2005 to $2012,70 \%-80 \%$ of all construction enterprises were small enterprises with $0-9$ employees; it was also affected by socio-economic factors in the country and lack of big enterprises. In order to understand the current state of the industry, it is also important to analyze the overall work efficiency of the industry merchants. Fig. 5 shows the financial profitability of the real estate operations in comparison with the average financial profitability indices of all industries. Financial profitability shows the amount of profit the company has gained per unit of capital (Central Statistical Bureau of Latvia, 2014). 


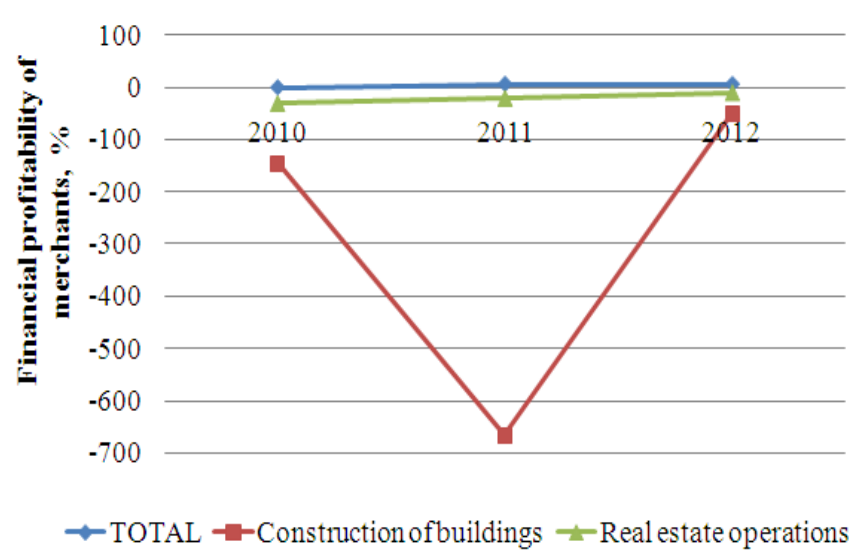

Fig. 5. Financial profitability of merchants (commercial companies), \% (NACE 2.red.) Data source: Central Statistical Bureau of Latvia, the line diagram was made by the authors.

Fig. 5 shows the negative index of financial profitability of the real estate operations during the period from 2010 to 2012; at the same time the merchant indices of the real estate operations, especially business industry merchants and especially in the construction industry are worse than the average indices of the all industries. Business failure within the sector could affect the company's partners and other involved parties, especially creditors, considerably more than in other sectors. It is shown in Fig. 6 that the ratio of construction and operations of the real estate industry in the balance is higher than the overall average index of other sectors. Successful regulation of the industry and professionalism of the entrepreneurs in the real estate industry could reduce existing industry risks.

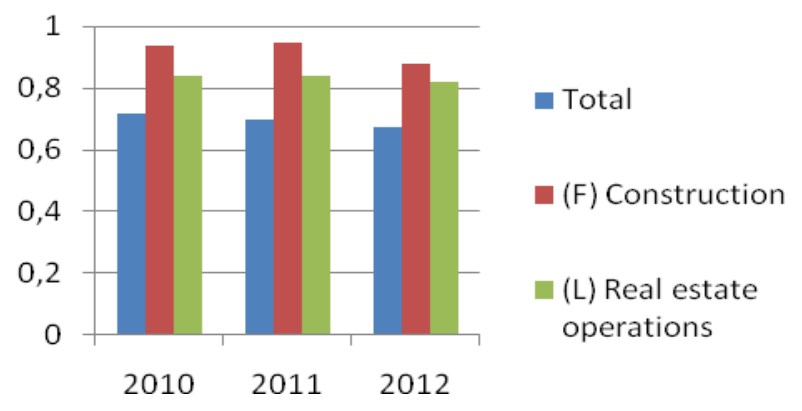

Fig. 6. Share of liabilities in the balance sheet (at the end of year, times) (NACE 2.red.) Data source: Central Statistical Bureau of Latvia, the bar chart was made by the authors.

Fig. 7 shows that the liquidity level of construction of building is also lower than an average liquidity index of all industries.

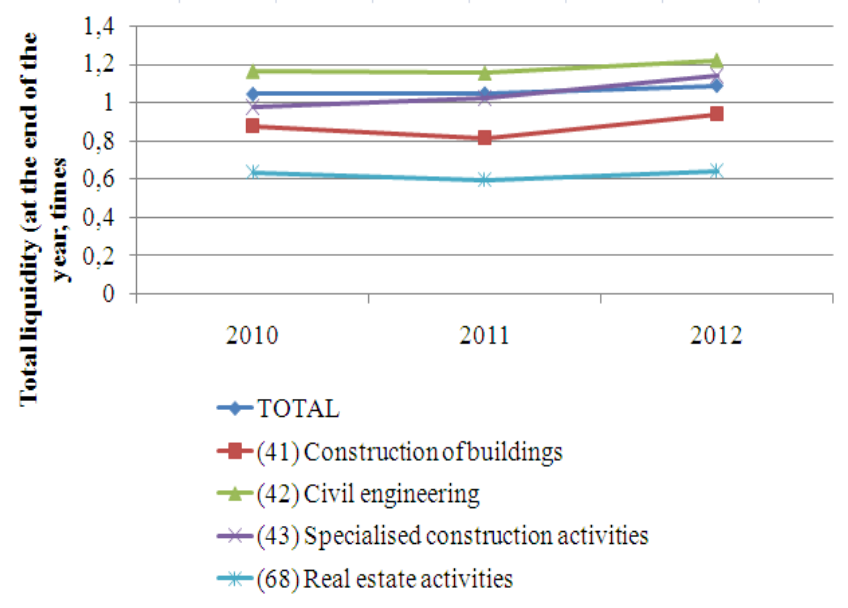

Fig. 7. Total liquidity of merchants (commercial companies), \% (NACE 2.red.) Data source: Central Statistical Bureau of Latvia, the line diagram was made by the authors.

It is important to mention that a liquidity index of real estate activities is lower than a liquidity index of all construction activities. Real estate trading market involves several taxes. Tax revenues from financial and capital transactions, value added tax revenues, as well as tax revenue from land, buildings or other structures are shown in Fig. 8. Taxes affect the financial planning of the real estate market participants. Taxes on financial and capital transactions have not been used in the Republic of Latvia until 2007, but after 2007 these taxes affect the real estate trading sector, such as capital gains tax. Fig. 8 also shows that state tax revenues relating to land, buildings and other structures, as well as revenues from valueadded taxes have increased in the period from 1995 to 2011. In the real estate industry it is also important to follow the total tax burden, as it also affects financial possibilities of the market participant and, hence, the activity level of the industry.

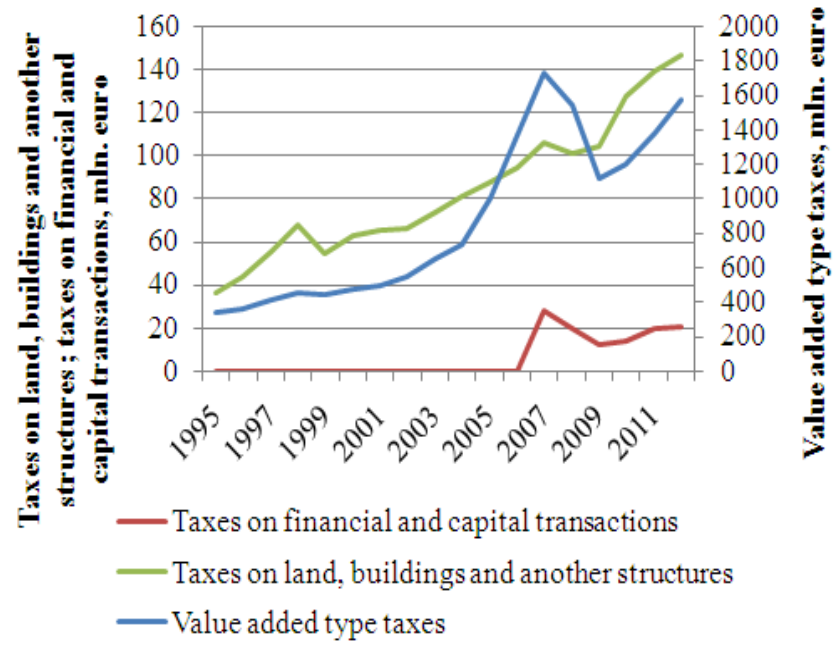

Fig. 8. Detailed tax and social contribution receipts by type of tax or social contribution of general government by sub-sectors (mln euro). Data source: Central Statistical Bureau of Latvia, the line diagram was made by the authors. 
Barriers to entry the construction sector are higher than to the real estate trading sector, as they often require the largest amount of funds, as well as there are difficulties due to a limited choice of land and other real estate sites. In order to better understand the peculiarities of the real estate industry, the authors of the study have prepared a questionnaire, which was completed by 54 people mostly working in the real estate trading sector. The majority of respondents - $44 \%$ - have chosen the insufficient demand as the most important factor slowing the operation of the companies in the real estate trading industry, followed by a high level of competition in the industry (see Fig. 9).

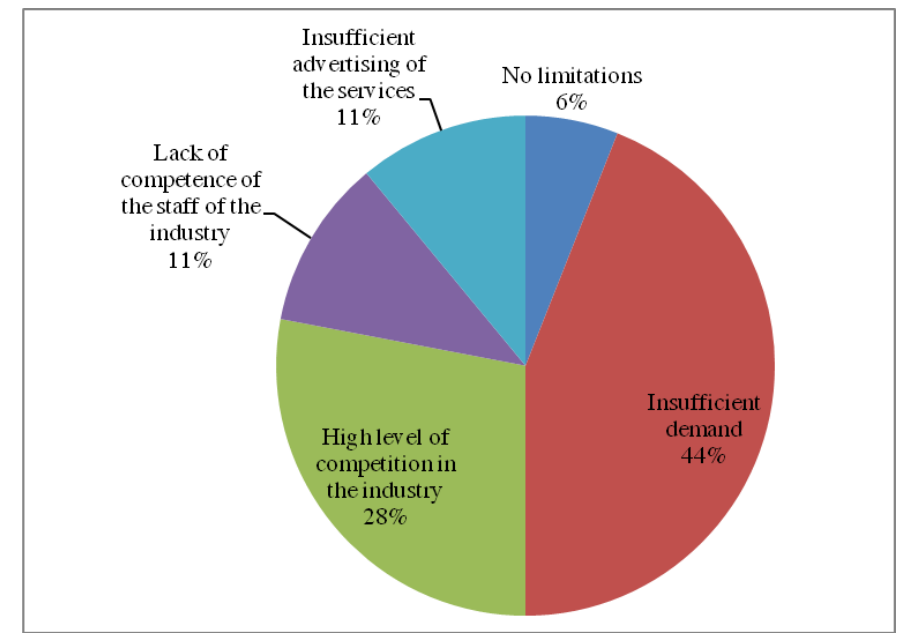

Fig. 9. Factors slowing real estate industry development, the pie chart was made by the authors.

According to the study results, from the perspective of the customers, the most important element of 9C complex in the real estate market is the level of personnel competence $(29 \%$ of respondents), as well as the satisfaction of customer needs and desires $-23 \%$ of respondents (see Fig. 10).

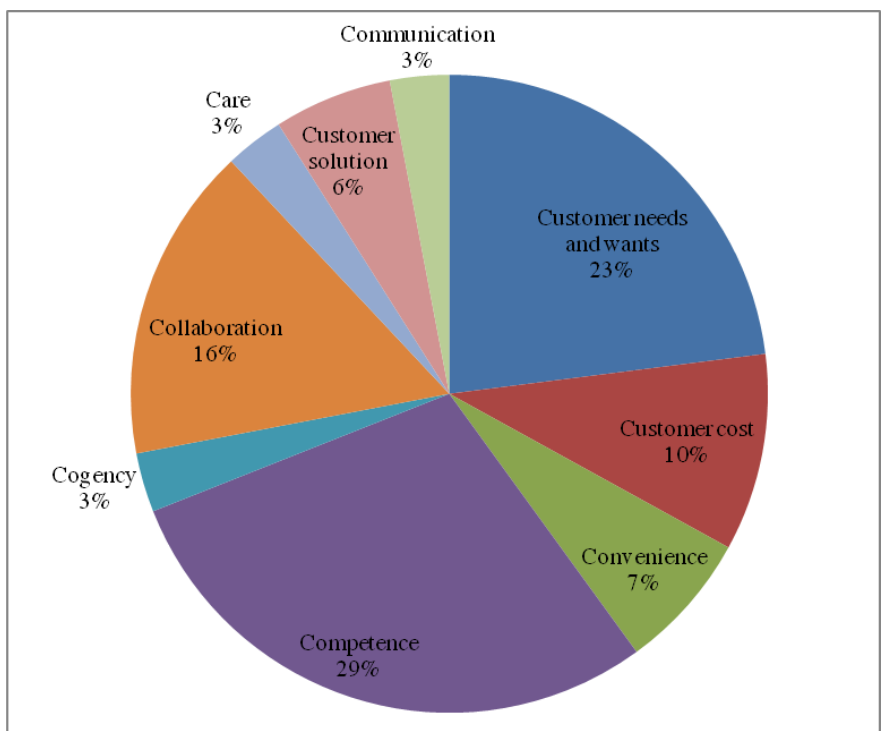

Fig. 10. 9C complex elements according to the degree of importance from the customers' perspective for construction branch and real estate activities, the pie chart was made by the authors.
The above-mentioned results highlight the level of competence of employees, satisfaction of quality of service and customer needs in the company's activities. Real estate transaction enterprise should also expand the offering in order to increase the choice of the objects for potential customers. The co-operation between the customer and the company's employees is also important, so the workforce competence requires special attention.

\section{CONCLUSION}

Real estate mediation field also presents high significance of external factors. During the analysis, it can be concluded that the real estate field is also significantly influenced by overall national trends. The overall economic development and real estate market development affect the real estate price level, and in the researched period real estate price fluctuations in Latvia are much more pronounced than the consumer price fluctuations. Price fluctuations affect changes in demand and the number of transactions in the industry, which, in turn, significantly influence the financial performance of the companies in the sector. In the time period from 2005 to $2012,70 \%-80 \%$ of all construction enterprises were small enterprises with number of employees from 0 to 9 . It was also affected by socio-economic factors in the country and lack of big enterprises. Liquidity level of construction of building is also lower than an average liquidity index of all industries. It is important to mention that a liquidity index of real estate activities is lower than that in the construction industry. Business failure within the sector could affect the company's partners and other involved parties, especially creditors, much more than in other sectors. According to the conducted research, the ratio of construction and operations of the real estate industry in Latvia is higher than the overall average index of other sectors. Successful regulation of the industry and professionalism of the entrepreneurs in the real estate industry could reduce existing risks. A majority of respondents $(44 \%)$ have chosen the insufficient demand as the most important factor slowing the operation of the companies in the real estate trading industry, followed by a high level of competition in the industry (28\%). Results of this study highlight the level of competence of employees, satisfaction of quality of service and customer needs in the company's activities. The company personnel and their level of competence have a significant role in the real estate trading sector, because it significantly affects the quality of the service provided. The companies are recommended to develop the quality planning system of company, as well as to provide additional services; it also involves the problem of employee turnover and lack of highly skilled employees with a high level of competence, so the people management is important for the companies operating in the industry. Before hiring new staff, it is important to assess the need for their training. Special attention should also be paid to direct sales skills.

The role of the state in the real estate market and the overall regulation of the national economy are important, as the income from real estate sales partially migrates to other 
sectors of the national economy, thus providing a positive impact on the overall development of the country. Government institutions should make more use of other countries' positive experience in market regulation, as well as should effectively apply the fiscal and monetary policy instruments. Successful regulation of the industry and professionalism of the entrepreneurs in the real estate industry could reduce existing industry risks.

\section{REFERENCES}

Asaul, A. N. (2004). Ekonomika nedvizhimosti [Real Estate Economics]. Piter: "Piter", p. 512.

Buzyrev, V. (2009) Ekonomika Stroitelstva [Construction Economics] (3rd ed.). St.Petersbourg: Ltd. „Lider”.p. 416. ISBN 978-5-49807-127-5.

Central Statistical Bureau of Latvia (2014). Statistic database. Retrieved from http://www.csb.gov.lv/dati/statistikas-datubazes-28270.html

Central Statistical Bureau of Latvia. (2014). Definitions of financial indicators financial profitability. Retrieved from http://www.csb.gov.lv/statistikastemas/termini/finansiala-rentabilitate-35096.html

Denisovs, M, \& Judrupa, I. (2008). Reg̣ionu attīstības un konkurētspējas novērtēšana [Evaluation of Regional Development and Competitiveness]. Riga: RTU Publishing House. p. 70.

European statistics database Eurostat. (2014). Statistics database. Retrieved from http://epp.eurostat.ec.europa.eu/portal/page/portal/statistics/search_database

Forands, I. (2009). Biznesa vadības tehnologijas [Business Management Technologies] (2 ${ }^{\text {nd }}$ ed.). Riga: Latvijas Izglītības fonds, p. 131.

Geipele, I. (2007). Tirgvedības stratēgiskā vadīšana uznēmumā [Strategic Marketing Management in Construction Sector]. Riga: RTU Publishing house. p. 318 .

Gielnik, M. M, Barabas, S., Frese, M., Namatovu-Dawa, R, Scholz, F. A., Metzger, J. R. \& Walter, T. (2014). A Temporal Analysis of how Entrepreneurial Goal Intentions, Positive Fantasies, and Action Planning Affect Starting a New Venture and when the Effects Wear off. Journal of Business Venturing, 29, pp. 755-772. http://dx.doi.org/10.1016/j.jbusvent.2013.09.002

Kuratko, D. F., Hornsby, J. S. \& Covin J. (2014). Diagnosing a Firm's Internal Environment for Corporate Entrepreneurship. Business Horizons 57, pp. 37-47. http://dx.doi.org/10.1016/j.bushor.2013.08.009

Lapigin, Y., \& Lapigin, D. (2009). Upravlencheskie reshenija [Management decisions]. Moskva: Eksmo. p. 448.

Leilands, J. (2009). Kvalitātes vadības sistēmas: jaunā ISO 9001:2008 standarta prasību skaidrojums [Quality Management System. The explanation of the requirements of new standard ISO 9001: 2008]. Riga: Latvijas Vēstnesis. p. 176.

Liu, J., \& London K. (2013). Modelling housing supply and monetary policy within the context of global economic turbulence. International Journal of Strategic Property Management, 17(1): pp. 1-20, http://dx.doi.org/10.3846/1648715X.2012.735273

Shane, S. \& DelmaR, F. (2004). Planning for the Market: Business Planning Before Marketing and the Continuation of Organizing Efforts. Journal of Business Venturing, 19, pp. 767-785. http://dx.doi.org/10.1016/j.jbusvent.2003.11.001

Uzulāns, J. (2004). Projektu vadība [Project management]. Riga: SIA „J.L.V.”, p. 244.

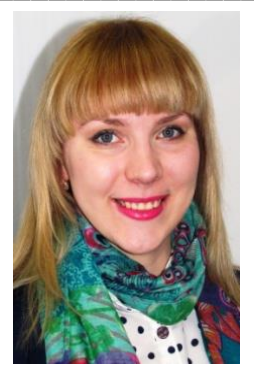

Linda Kauškale is the $\mathrm{PhD}$ student, Researcher at Riga Technical University, Faculty of Engineering Economics and Management. She graduated with distinction and obtained the Professional Master Degree in Civil Construction and Real Estate Management and qualification of Real Estate Economist. She is the Head of International Real Estate Department at Ltd. AVA HOLDING. Participation in scientific conferences: International Conference on Environmental Engineering (ICEE2014); Modern Building Materials, Structures and Techniques (MBMST-2013), Vilnius, Lithuania, etc. Research focus - real estate market analysis, influence of real estate market cycle and economic cycle on development, interaction of socio-economic factors of entrepreneurship in real estate market and construction branch etc. Year 2014 - RTU Gold Fund graduate. Fall 2013 - FIABCI (International Real Estate Federation) grantee.

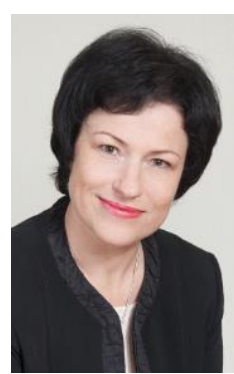

Ineta Geipele is the Professor at the Faculty of Engineering Economics and Management, the Head of the Institute of Civil Engineering and Real Estate Economics, the Head of the Chair of Civil Construction and Real Estate Economics and Management of Riga Technical University (RTU), Latvia. She has earned her Doctor's degree of Economics and Master's degree of Economics in Engineering Sciences at RTU. Her professional skills are improved in Austria, Germany, Denmark and England. She is the author and co-author of more than 180 scientific publications. Her current research interests are focused on sustainability development problems of real estate market, construction industry, including land use management and institutional economics. She is an expert in Management Science of the Latvian Council of Science, a board member: of the FIABCI-Baltic Multinational Chapter; of the Cunfte of the Facility Management of Latvian Housing, a Member of the Latvian Union of Civil Engineers etc. 